\title{
Article \\ Effects of Gap Size and Cardinal Directions on Natural Regeneration, Growth Dynamics of Trees outside the Gaps and Soil Properties in European Beech Forests of Southern Italy
}

\author{
Silvio Bagnato, Pasquale A. Marziliano (D), Maria Sidari, Carmelo Mallamaci, Federica Marra \\ and Adele Muscolo *(iD)
}

check for updates

Citation: Bagnato, S.; Marziliano, P.A.; Sidari, M.; Mallamaci, C.; Marra, F.; Muscolo, A. Effects of Gap Size and Cardinal Directions on Natural Regeneration, Growth Dynamics of Trees outside the Gaps and Soil Properties in European Beech Forests of Southern Italy. Forests 2021, 12 , 1563. https://doi.org/10.3390/ f12111563

Academic Editor: Keizo Hirai

Received: 7 October 2021

Accepted: 9 November 2021

Published: 12 November 2021

Publisher's Note: MDPI stays neutral with regard to jurisdictional claims in published maps and institutional affiliations.

Copyright: (c) 2021 by the authors. Licensee MDPI, Basel, Switzerland. This article is an open access article distributed under the terms and conditions of the Creative Commons Attribution (CC BY) license (https:// creativecommons.org/licenses/by/ $4.0 /)$.
Department of AGRARIA, “Mediterranea” University, Feo di Vito, 89122 Reggio Calabria, Italy; silvio.bagnato@unirc.it (S.B.); pasquale.marziliano@unirc.it (P.A.M.); msidari@unirc.it (M.S.); carmelo.mallamaci@unirc.it (C.M.); federica.marra@unirc.it (F.M.)

* Correspondence: amuscolo@unirc.it; Tel.: +39-09651694364

Abstract: The present study was focused on how cardinal directions inside gaps of different sizes (small, $200 \mathrm{~m}^{2}$; medium, $400 \mathrm{~m}^{2}$; and large, $600 \mathrm{~m}^{2}$ ) can affect soil characteristics and tree regeneration. Additionally, the effects of gap size on the growth dynamics of trees outside the gaps were evaluated. The study was carried out in a European beech stand located in Aspromonte National Park (Southern Apennines, Calabria, Italy). Microclimatic variables, physical, chemical, and biochemical soil properties, natural regeneration density, and growth trees outside the gaps density of natural regeneration were assessed. This study provided evidence for an important effect of cardinal points on micro-environmental parameter variability, nutrient cycle, physic-chemical soil properties, water availability, and biological processes such as trees growth and regeneration. The European beech natural regeneration was most abundant in the south part of the gaps. Thus, we can state that cardinal points affect the trees natural regeneration in a species-specific manner. The new microclimatic conditions due to the gap opening had positive effects on the tree growth located along the gap edge, especially in the trees sampled on the edges of the medium gaps. On the contrary, the trees located in the forest recorded a productivity coherent with the period prior the gap opening. In medium-sized gaps, the combination and interaction of microclimatic and soil parameters (humification and mineralization process and microbial activity) created the best conditions for beech natural regeneration and favored an increase in the productivity of the trees at the edge of the gaps.

Keywords: biodiversity; cardinal points; Fagus sylvatica L.; gap sizes; natural regeneration; soil properties

\section{Introduction}

Forests, a provision source of raw material for industrial timber products, have always been managed to optimize timber production. However, the silvicultural practices often adopted caused a homogenization of forest landscapes at the expense of biodiversity [1]. Italy is the European country with the richest forest biodiversity and the most favorable geographical position for a wide variety of geological, climatic, and vegetation conditions [2,3]. However, a management aimed at guaranteeing a maximum and constant timber production has led to structural simplification of the forests (especially silver-fir, spruce, and beech forests) and a reduction of forest ecosystem complexity [4]. To preserve the complex dynamic of forest ecosystems, in recent decades special emphasis was placed on designing forest treatments that mimic natural processes and disturbances (close-tonature silviculture) to promote and preserve biodiversity and ecosystem functioning [5-7]. Forest disturbances have been an integral part of European forests for centuries, but they are not a threat for forests. Rather, they promote heterogeneity at multiple spatial scales, favoring ecological resilience [8]. Natural disturbances can be considered the main drivers of changes in environmental conditions $[8,9]$. For instance, in a forest the death of a single 
tree or of several neighboring trees creates gaps, which can cause changes in light levels, temperature, soil moisture, nutrient availability, and the regeneration of microsites associated with snapped or uprooted trees [10]. All of these factors, singularly or in combination with others, can affect tree growth, survival, and reproduction $[9,11,12]$. In the central and southern European mountains, forest gaps, often caused by natural disturbances, are ideal conditions for rapid tree reproduction and growth $[13,14]$. Gaps can range from small openings formed from the death of a single tree, medium openings formed by the asynchronous mortality of multiple trees, to large opening related to periodic storm events [10]. Gaps, in addition to being different for size, differ also in severity and frequency $[8,11]$ and can trigger dynamic processes of forest species settlement, which causing change in composition, structure, and age [15-17], creating heterogeneity in forests [18,19]. Apart from the gap sizes, the cardinal points inside of gaps also influence the microclimatic conditions $[20,21]$ and consequent germination and growth of tree species, playing a crucial role in the distribution of the vegetation patterns [9,22-24]).

In this study, we focused on the European beech (Fagus sylvatica L.), widespread across the Europe, and one of the most investigated forest species for its economic and ecological importance $[25,26]$. Some studies carried out in this species revealed relatively small gap sizes $\left(<200 \mathrm{~m}^{2}\right)$, suggesting that the European beech forests are predominantly driven by endogenous events with occasional intermediate disturbances, especially windthrows [27-29].

Several studies carried out in recent years on the regeneration in gaps of European beech analyzed mostly some gap characteristics, such as size or shape $[10,24,30,31]$ and light environment $[9,21]$, but few studies were focused on the effects that the cardinal points inside a gap have on tree regeneration $[9,32,33]$. Most of these studies were carried out in Central and Eastern Europe, but few have been conducted in the mountains of the Mediterranean region. Thus, understanding the dynamics of regeneration processes not only in respect to the gap of different sizes but rather in respect to the cardinal points inside the gaps remains an important task for guiding ecological forest management in the Mediterranean mountain forests where climatic conditions change in respect to cardinal directions, affecting, in turn, tree regeneration dynamics. It is generally stated that the germination and survival of beech seedlings are problematic and that climatic conditions play a key role in its regeneration. Thus, the novelty of this study is to identify the most favorable position in the gap of different sizes for European beech natural regeneration and growth in a beech stands of the Apennines Mountain in southern Italy. The main objectives were to evaluate if and how the cardinal directions inside the gaps can influence beech natural regeneration and if the gap opening has an effect on the growth of trees outside the gaps (both at the gap edges and in the closed forest). This information can be fundamental to increase its competitive ability under climatic change conditions. The specific objectives were: (a) to identify what is the best gap size and the most effective cardinal direction to encourage greater regeneration of beech; (b) to verify if there are significant relationships among environmental factors (photosynthetically active radiation, soil moisture, and temperature), gap sizes, cardinal directions, soil properties, and beech natural regeneration; and (c) to verify if there are significant relationship among gap sizes and growth of the old trees, both at the gap edges and in the closed forest.

\section{Material and Methods}

\subsection{Study Sites}

The study was carried out within a European beech (Fagus sylvatica L.) high forest, located in Aspromonte National Park (Southern Apennines, Calabria, Italy), in the southeast of Sarno village $(\mathrm{RC})\left(38^{\circ} 13^{\prime} \mathrm{N}, 15^{\circ} 96^{\prime} \mathrm{E}\right)$. The forests here observed is on a plateau at an altitude of about $1450 \mathrm{~m}$ a.s.l. on a flat terrain. Soil, developed mainly from gneiss and schist parent materials, is classified as Eutric Cambisols [34]. Mean annual rainfall is approximately $1603 \mathrm{~mm}$, with a minimum of precipitation in summer $(108 \mathrm{~mm})$. The annual number of rainy days is equal to 113 . The snowfalls are frequent in the period from December to March. Mean annual temperatures $\left(10.5^{\circ} \mathrm{C}\right)$ range from a minimum 
of $2.5^{\circ} \mathrm{C}$ in January to a maximum of $18.1{ }^{\circ} \mathrm{C}$ in August. According to the bioclimatic indices of Rivas-Martinez (1996) [35], the type of temperate, namely oceanic subtype, affects the territory. The forest stand is dominated by European beech (Fagus sylvatica L.), with sporadic occurrence of silver-fir (Abies alba Mill), Calabrian pine (Pinus nigra Arnold subsp. calabrica), and durmast oak (Quercus petraea ssp. austrotyrrhenica Brullo, Guarino and Siracusa). The shrub layer is nearly absent, but the forest floor is covered with a dense herb-layer. Most frequent species are Campanula trichocalycina Ten., Viola reichembachiana Jord. ex Boreau, Neottia nidus-avis (L.) Rich., Lamium flexuosum Ten. The beech stand examined (extending about 3000 hectares) is of natural origin, with a dominant age ranging from 90 to 140 years old. In 2019, the beech forest examined had a volume of $795 \mathrm{~m}^{3} \mathrm{ha}^{-1}$, a basal area of $61 \mathrm{~m}^{2} \mathrm{ha}^{-1}$, a dominant height of $25.4 \mathrm{~m}$, and a density of 850 trees ha ${ }^{-1}$. The diameters at breast height $(\mathrm{DBH})$ ranged from 10 to $80 \mathrm{~cm}$, with an average $\mathrm{DBH}$ of $30 \mathrm{~cm}$. The forest evolved naturally in the last 70 years. However, in the Southern Apennines until the Second World War beech forests had a very interesting management situation, based on a selection cutting, where felling of some big old trees opened up space for new regeneration [36-39]. This type of management created a small group structure, made up of trees of different age [37,40]. Particularly in the beech forest of this study, the traditional system consisted of a selection cut which eliminated the biggest trees and which is repeated at short intervals (8-10 years). This type of felling created small gaps (40 to $100 \mathrm{~m}^{2}$ in size) where beech regeneration quickly sets in $[37,41]$.

\subsection{Gap Opening}

During the autumn of 2009, an experimental design to randomized blocks was realized, with three treatments repeated three times. In detail, in the study site nine circular gaps were created: three smalls $\left(200 \mathrm{~m}^{2}\right)$, three medium $\left(400 \mathrm{~m}^{2}\right)$, and three large ones $\left(600 \mathrm{~m}^{2}\right)$, removing all trees from the gap areas. The gaps were separated from each other by a minimum distance of around $100 \mathrm{~m}$ on each direction in order to avoid a "border effect". After the cutting, to protect the beech natural regeneration from cattle grazing, each gap was fenced with a net $1.50 \mathrm{~m}$ high. Small, medium, and large are relative terms used only to separate the three gap sizes evaluated in this study as other published studies have wide-ranging definitions of small, medium, and large canopy gap opening sizes [15,41,42]. However, in this study the selection of experimenting these gap sizes is due to the practice of forest operators to carry out cuts in managed stands, that create hole openings ranging from 150-200 to 600-700 $\mathrm{m}^{2}$. Each gap was paired with an adjacent under canopy cover site located $25-30 \mathrm{~m}$ from the edge of the gap.

Nine circular sub-plots of $3.14 \mathrm{~m}^{2}$ (100 cm radius) were established inside each gap. In detail, (i) one sub-plot was positioned in the centre of each gap (C); (ii) four sub-plot were located at one-half of the radius starting from the centre to the gap edge along the cardinal directions (1N, 1E; 1S, 1W); and (iii) four sub-plot were located at the edge of gap along the cardinal directions (2N, 2E, 2S, 2W) (Figure 1). A total of 81 sub-plot were established, 27 for each gap size. The area covered by the subplots referred to points (i) and (ii) was defined as the "center of a gap", while the area covered by the subplots referred to point (iii) was defined as the "gap edge".

\subsection{Soil Analysis}

2.3.1. Measurement of Soil Temperature, Soil Moisture and Photosynthetically Active Radiation

Soil temperature, soil moisture and photosynthetically active radiation (PAR) (hereafter defined as microclimatic variables) were measured in each subplot of each gap and in its adjacent forest canopy cover site. Particularly, soil temperature thermometer (Elite) was placed at $10 \mathrm{~cm}$ depth from the top of in the mineral soil. It was calculated by weighing the wet soil sampled from the field, drying it in an oven, and then weighing the dry soil. Thus, the gravimetric water content equals the wet soil mass minus the dry soil mass divided by the dry soil mass. This parameter was measured at 12.00 during the period between May 
and September 2019. Soil moisture content was determined gravimetrically in samples collected from 0 to $10 \mathrm{~cm}$ depth. The measurements of photosynthetically active radiation (PAR) were carried out monthly, during the period from May to September 2019 on clear days, at $12.00 \mathrm{~h}$. PAR levels were measured using a Ceptometer (AccuPAR, Degagon Devices Inc., Pullman, WA, USA), at $1.00 \mathrm{~m}$ above the ground, with the instrument held horizontally [43]. Corresponding PAR values were used to calculate PAR transmittance using the following formula [1]:

$$
\text { Trasmittance PAR }=\frac{\text { PAR subplot }}{\text { PAR full open }} \times 100
$$

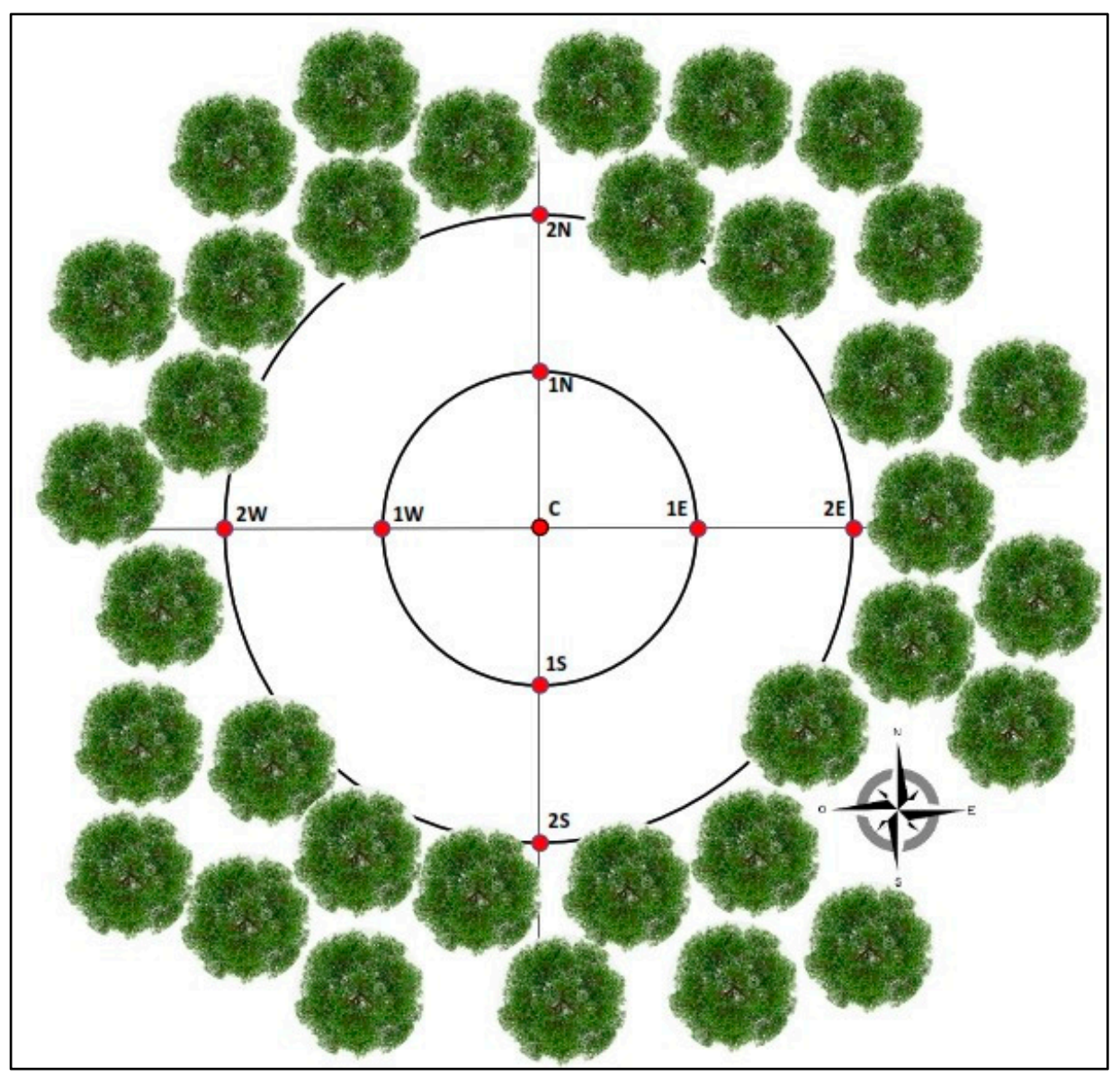

Figure 1. Plot design composed by nine circular subplots. The area of sub-plots $C$ (center of each gap) and $1 \mathrm{~N}, 1 \mathrm{~S}, 1 \mathrm{E}$, and $1 \mathrm{~W}$ (sub-plots along the cardinal directions) was defined as the "center", while the area of sub-plots $2 \mathrm{~N}, 2 \mathrm{~S}, 2 \mathrm{E}$, and $2 \mathrm{~W}$ was defined as the "edge".

\subsubsection{Measurement of Soil Chemical and Physical Properties}

During the period from May to September 2019 (10 years after gap opening), mineral soil samples (0-15 cm depth) were collected in triplicate in each subplot of each gap, and in its adjacent forest canopy cover site. Prior to the soil analysis, except for soil moisture content and enzymatic analysis, all the soil samples were air-dried and sieved $(<2 \mathrm{~mm})$. For each soil sample, the following parameters have been determined or calculated: $\mathrm{pH}$; organic carbon (OC); organic matter (OM); total nitrogen $(\mathrm{N}) ; \mathrm{C} / \mathrm{N}$ ratio; the total carbonates, expressed as $\mathrm{CaCO}_{3}$; the water-soluble phenol (WSP); the exchangeable potassium $\left(\mathrm{K}^{+}\right)$; the hydrolysis of fluorescein diacetate (FDA); the activity of dehydrogenase (DHA); microbial biomass carbon (MBC). 
Particle size analysis was carried out by the hydrometer method using sodium hexametaphosphate as a dispersant [44]; $\mathrm{pH}$ was measured in distilled water and $1 \mathrm{M} \mathrm{KCl}$ (soil:solution ratio 1:2.5) with a glass electrode; organic carbon was determined by dichromate oxidation [45], and it was converted to organic matter by multiplying the percentage of carbon by 1.72; total nitrogen was measured by the Kjeldahl method [46]. Exchangeable potassium was determined by flame photometry after extraction with $1 \mathrm{M}$ NH4OAc.

Phenols were extracted with distilled water $[47,48]$, total water-soluble phenols were determined by using the Folin-Ciocalteau reagent [49], tannic acid was used as a standard and the concentration of water-soluble phenolic compounds was expressed as tannic acid

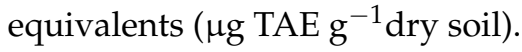

Microbial biomass $C$ was determined by the chloroform fumigation-extraction procedure [50]. The filtered soil extracts of both fumigated and unfumigated samples were analyzed for soluble organic C [45].

FDA hydrolysis reaction was determined according to the methods of Adam and Duncan [51]. Dehydrogenase (DHA) activity was determined as reported in Muscolo et al. [52].

\subsection{Natural Regeneration, Tree Sampling, Ring Width and BAI Analyses}

In October 2019 (10 years after the gap's opening), all seedlings found inside each sub-plot were counted. On 72 trees located in the edge of the gaps and on 36 trees located in forest outside the gaps, two increment cores per trees were collected at breast height and at an angle of $120^{\circ}$ to each other. The tree cores were taken from two dominant trees for each cardinal direction (N-E-S-W) at the outer edges of each gap and from four dominant trees within the forest, near each gap. Cores were then mounted on channeled wood, seasoned in a fresh-air dry store and sanded a few weeks later. Tree-ring widths were measured with a resolution of $0.01 \mathrm{~mm}$ using the LINTAB measurement equipment (Frank Rinn, Heidelberg, Germany) fitted with a Leica MS5 stereoscope (Leica Microsystems, Wetzlar, Germany). Tree ring widths were then statistically cross-dated and verified with the software TSAP software package (version 4.81c). Once all measurement series were validated, tree-ring chronologies were developed. Subsequently, tree ring widths were converted into tree basal area increment (BAI), according to the following standard formula [2]:

$$
B A I=\pi\left(r_{n}^{2}-r_{n-1}^{2}\right)
$$

where $r$ is the radius of the stem at breast height and $n$ is the year of tree-ring formation.

For each core, we considered the tree ring chronologies of the 15 years preceding the gap's opening (1995-2009) and of the 10 years following the gap's opening were considered (2009-2019). In the first case, the average current annual increment was calculated as $\mathrm{r} 15 / 15$ [53]. where $\mathrm{r} 15$ is the radius increment recorded in the 15 years before of the opening of the gaps. In the second case, as $\mathrm{r} 10 / 10$ where $\mathrm{r} 10$ is the radius increment recorded in the 10 years following the opening of the gaps.

\subsection{Statistical Analysis}

On an exploratory level, after checking the normality of the raw values, in each gap the regeneration density data and the microclimatic variables (PAR, soil moisture and soil temperature) were scattered against each other to gain a general understanding of their relationships, through the Pearson correlation coefficient. Furthermore, we tested if the interaction between microclimatic variables may influence the regeneration density. Afterwards, the analysis of variance (ANOVA) was carried out to determine the effect of gap size on microclimatic variables (PAR, soil moisture and soil temperature) and on physical and chemical soil properties. In addition, for each gap an ANOVA was carried out to determine the effect of position (center, edge) and cardinal direction (N, E, S, W) on the same variables as above. For all analysis, when ANOVA indicated an overall significant effect, the Tukey's test examined which pairs differed significantly. 
For beech regeneration density, we tested the differences in the beech regeneration counts (number of seedlings per $\mathrm{m}^{2}$ ), considering several categorical predictor variables. Particularly, we used the following predictor variables: gap size (200-400-600 $\left.\mathrm{m}^{2}\right)$, subplot position within the gap (center, edge), cardinal direction on which each subplot was situated $(\mathrm{N}, \mathrm{E}, \mathrm{S}, \mathrm{W})$. To evaluate the effect of predictor variables on seedling counts we used a negative binomial generalized linear model (nbGLM). In the model, we also tested the interaction between predictive variables. The analyses were conducted with $\mathrm{R}$ software, version 4.1.0 (R Core Team 2021) using the MASS package.

\section{Results}

\subsection{Soil Properties}

\subsubsection{Soil Temperature, Soil Moisture and PAR}

PAR transmittance was significantly higher $\left(\mathrm{F}_{(1,14)}=135.17 ; p<0.001\right)$ in gaps $(47.4 \%)$ than in forest site $(1.5 \%)$ and significantly increased with increasing gap size $\left(\mathrm{F}_{(2,76)}=3.145\right.$; $p=0.043)$. The highest values were always recorded in the center of the gap, but with significant differences compared to the edge only for medium and large gaps. In all gaps, PAR was significantly higher in the north and west position $(p \leq 0.05)$. The lowest PAR values were recorded in the south position of the gaps (Figure 2).

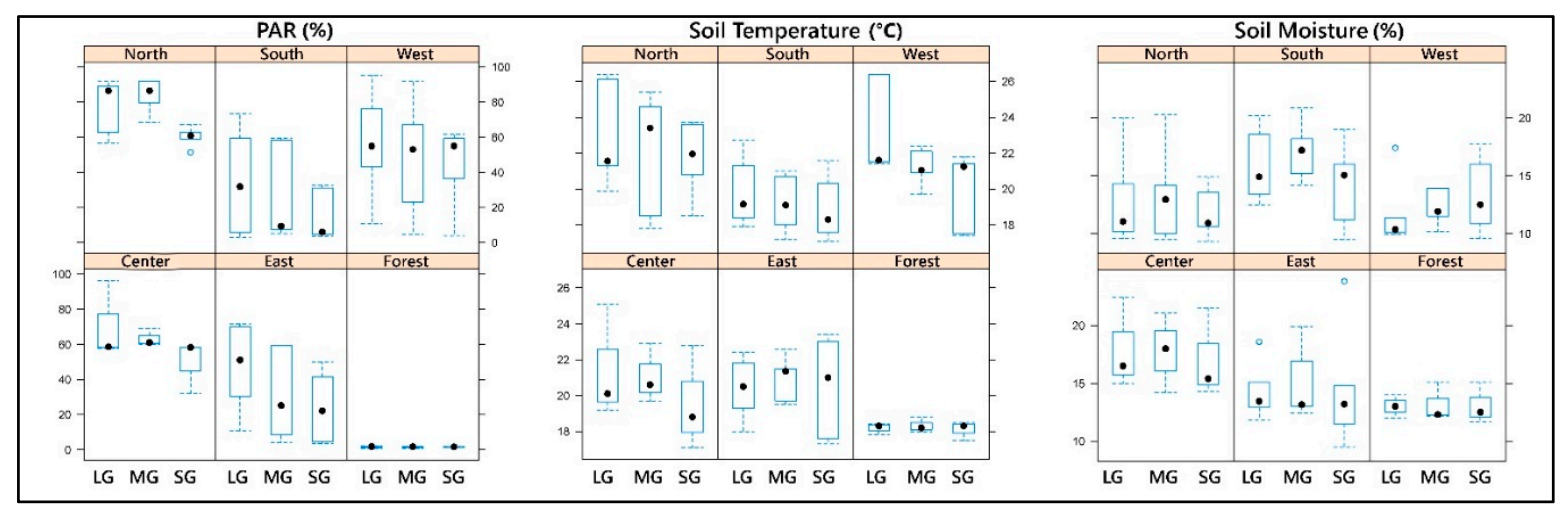

Figure 2. Median values and related variability of Photosynthetically active radiation (PAR), Soil temperature and Soil moisture in each gap size for each cardinal point and in forest. LG, large gap; MG, medium gap; SG, small gap. The solid dot indicates the median values. In the box, the lower limit corresponds to the value of the first quartile (Q1) of the distribution and the upper limit to the third quartile (Q3); the vertical lines (whiskers) delimit the intervals in which the lower values of Q1 (in the lower part) and the greater values of Q2 (in the upper part) are positioned. Outliers are reported as empty dots.

In each gap size, the soil temperature was significantly greater in gaps (on average $20.9^{\circ} \mathrm{C}$ ) than in forest site (on average $\left.18.5^{\circ} \mathrm{C}\right)\left(\mathrm{F}_{(1,14)}=18.072 ; p \leq 0.001\right)$. On average, the soil temperatures inside the gaps were between 20.4 and $21.5^{\circ} \mathrm{C}$ and increased with increasing gap size, with significant differences between small and large gaps $\left(\mathrm{F}_{(2,75)}=3.702\right.$; $p=0.026)$. In each gap, the temperature differences among the cardinal directions were not significant $(p>0.05)$; however, the highest soil temperatures were recorded always in north and west position (Figure 2).

Soil moisture was higher in gaps $(14.2 \%)$ than in forest site $(13.1 \%)$, but without significant differences $\left(\mathrm{F}_{(1,14)}=2.690 ; p=0.123\right)$. In the medium gap, the soil moisture was higher $(14.7 \%)$, but with no significant differences with soil moisture in small and large gap $\left(\mathrm{F}_{(2,76)}=0.745 ; p=0.478\right)$. In each gap size, the soil moisture was the highest in the central area, with significant differences compared to the edge $(p<0.001)$. In all gaps, the moisture was significantly higher in the south than the other cardinal directions $(p<0.001)$ (Figure 2). 


\subsubsection{Soil Chemical and Physical Properties}

Selected physical and chemical properties of soils detected in the center and in the four cardinal directions of the large, medium, and small gaps are shown in Tables 1 and 2. In all sites, independently from gap size and cardinal points, the soil texture was loamy-sand, total carbonates were absent, the soils were acid, with $\mathrm{pH}$ ranging from 5.5 to 5.9 , with no statistically significant differences $(p=0.65)$ (Table 1$)$. Soil organic matter $(\mathrm{OM})($ Table 2$)$ was significantly higher $(p \leq 0.05)$ in forest site than in the gaps, and it was significantly higher $(p \leq 0.05)$ in the medium gaps compared to large and small gaps. However, no significant differences in the OM content were detected among the center and the 4 cardinal directions inside each gap. Nitrogen was higher $(p \leq 0.05)$ in the forest than in the gaps and increased with increasing gap size. $\mathrm{N}$ was higher in south than in the other cardinal directions and the center in all gaps. The $\mathrm{C} / \mathrm{N}$ ratio was significantly higher $(p \leq 0.05)$ in small and in medium gaps compared to large gap and forest site it was lower in the south than in the other cardinal directions $(p \leq 0.05)$.

Table 1. Chemical characteristics of soils in each gap size for each cardinal points, in center of gap (CEN) and in forest.

\begin{tabular}{|c|c|c|c|c|c|c|c|}
\hline Gap & Position & $\mathrm{pH}$ & Sand \% & Silt \% & Clay \% & $\begin{array}{c}\text { Textural } \\
\text { Class }\end{array}$ & $\mathrm{CaCO}_{3}$ \\
\hline \multirow[t]{6}{*}{ Small } & CEN & $5.5 \pm 0.13$ & $81 \pm 3$ & $11 \pm 2$ & $8 \pm 1$ & Loamy-sand & 0.0 \\
\hline & North & $5.6 \pm 0.09$ & $81 \pm 3$ & $11 \pm 2$ & $8 \pm 1$ & Loamy-sand & 0.0 \\
\hline & East & $5.8 \pm 0.10$ & $81 \pm 3$ & $11 \pm 2$ & $8 \pm 1$ & Loamy-sand & 0.0 \\
\hline & South & $5.5 \pm 0.11$ & $81 \pm 3$ & $11 \pm 2$ & $8 \pm 1$ & Loamy-sand & 0.0 \\
\hline & West & $5.6 \pm 0.07$ & $81 \pm 3$ & $11 \pm 2$ & $8 \pm 1$ & Loamy-sand & 0.0 \\
\hline & Forest & $5.8 \pm 0.09$ & $81 \pm 3$ & $11 \pm 2$ & $8 \pm 1$ & Loamy-sand & 0.0 \\
\hline \multirow[t]{6}{*}{ Medium } & CEN & $5.7 \pm 0.14$ & $80 \pm 4$ & $10 \pm 1$ & $10 \pm 2$ & Loamy-sand & 0.0 \\
\hline & North & $5.9 \pm 0.08$ & $80 \pm 4$ & $10 \pm 1$ & $10 \pm 2$ & Loamy-sand & 0.0 \\
\hline & East & $5.7 \pm 0.13$ & $80 \pm 4$ & $10 \pm 1$ & $10 \pm 2$ & Loamy-sand & 0.0 \\
\hline & South & $5.5 \pm 0.09$ & $80 \pm 4$ & $10 \pm 1$ & $10 \pm 2$ & Loamy-sand & 0.0 \\
\hline & West & $5.7 \pm 0.10$ & $80 \pm 4$ & $10 \pm 1$ & $10 \pm 2$ & Loamy-sand & 0.0 \\
\hline & Forest & $5.6 \pm 0.13$ & $80 \pm 4$ & $10 \pm 1$ & $10 \pm 2$ & Loamy-sand & 0.0 \\
\hline \multirow[t]{6}{*}{ Large } & CEN & $5.7 \pm 0.16$ & $78 \pm 3$ & $16 \pm 2$ & $8 \pm 1$ & Loamy-sand & 0.0 \\
\hline & North & $5.9 \pm 0.05$ & $78 \pm 3$ & $16 \pm 2$ & $8 \pm 1$ & Loamy-sand & 0.0 \\
\hline & East & $5.5 \pm 0.12$ & $78 \pm 3$ & $16 \pm 1$ & $8 \pm 1$ & Loamy-sand & 0.0 \\
\hline & South & $5.6 \pm 0.12$ & $78 \pm 3$ & $16 \pm 2$ & $8 \pm 1$ & Loamy-sand & 0.0 \\
\hline & West & $5.8 \pm 0.10$ & $78 \pm 2$ & $16 \pm 2$ & $8 \pm 1$ & Loamy-sand & 0.0 \\
\hline & Forest & $5.5 \pm 0.13$ & $78 \pm 1$ & $16 \pm 2$ & $8 \pm 1$ & Loamy-sand & 0.0 \\
\hline
\end{tabular}

Table 2. Chemical and biochemical soil properties in each gap size for each cardinal point, in center of gap (CEN) and in forest. Organic matter (OM, \%), water soluble phenols (WSP, $\mu \mathrm{g}$ TAE g ${ }^{-1}$ d.s), ammonium-nitrogen $\left(\mathrm{N}_{-} \mathrm{NH}_{4}{ }^{+}, \mathrm{mg} \mathrm{kg}^{-1} \mathrm{~d} . \mathrm{s}\right)$, carbon nitrogen ratio $(\mathrm{C} / \mathrm{N})$, fluorescein diacetate hydrolase (FDA, $\mu \mathrm{g}$ fluorescein released $\mathrm{g}^{-1} \mathrm{ds}$ ), dehydrogenase (DHA, $\mu \mathrm{g}$ INTF $\mathrm{g}^{-1}$ d.s. $\left.\mathrm{h}^{-1}\right)$, carbon $(\mathrm{C}, \%)$, nitrogen $\left(\mathrm{N}, \%\right.$ ), exchangeable potassium $\left(\mathrm{K}^{+} \mathrm{mg} \mathrm{Kg}^{-1}\right.$ d.s.), microbial biomass $\mathrm{C}$ $\left(\mathrm{MBC}, \mu \mathrm{g} \mathrm{C} \mathrm{g}^{-1}\right.$ f.s.).

\begin{tabular}{|c|c|c|c|c|c|}
\hline & & Small & Medium & Large & Forest \\
\hline \multirow[t]{5}{*}{$\mathrm{OM}$} & CEN & $6.2 \pm 0.8$ & $7.1 \pm 0.8$ & $6.3 \pm 1.1$ & $8.9 \pm 2.1$ \\
\hline & North & $5.5 \pm 1.1$ & $7.2 \pm 0.9$ & $6.5 \pm 1.0$ & \\
\hline & East & $5.6 \pm 1.3$ & $7.6 \pm 1.0$ & $6.0 \pm 0.7$ & \\
\hline & South & $7.6 \pm 2.2$ & $7.6 \pm 1.2$ & $6.5 \pm 0.9$ & \\
\hline & West & $6.9 \pm 1.1$ & $7.1 \pm 1.3$ & $5.8 \pm 2.5$ & \\
\hline \multirow[t]{5}{*}{ WSP } & CEN & $170 \pm 23$ & $177 \pm 35$ & $174 \pm 31$ & $148 \pm 15$ \\
\hline & North & $180 \pm 28$ & $178 \pm 17$ & $185 \pm 41$ & \\
\hline & East & $179 \pm 13$ & $171 \pm 34$ & $178 \pm 29$ & \\
\hline & South & $177 \pm 24$ & $174 \pm 36$ & $179 \pm 34$ & \\
\hline & West & $179 \pm 13$ & $176 \pm 38$ & $185 \pm 30$ & \\
\hline
\end{tabular}


Table 2. Cont.

\begin{tabular}{|c|c|c|c|c|c|}
\hline & & Small & Medium & Large & Forest \\
\hline \multirow[t]{5}{*}{$\mathrm{C} / \mathrm{N}$} & CEN & $27 \pm 6.5$ & $26 \pm 3.9$ & $19 \pm 3.3$ & $21 \pm 4.7$ \\
\hline & North & $26 \pm 9.7$ & $28 \pm 7.4$ & $19 \pm 2.6$ & \\
\hline & East & $29 \pm 5.0$ & $26 \pm 2.5$ & $20 \pm 4.1$ & \\
\hline & South & $23 \pm 9.7$ & $23 \pm 2.7$ & $15 \pm 1.8$ & \\
\hline & West & $22 \pm 7.1$ & $27 \pm 5.2$ & $20 \pm 4.4$ & \\
\hline \multirow[t]{5}{*}{ FDA } & CEN & $40 \pm 3.4$ & $50 \pm 8.3$ & $41 \pm 11.5$ & $61 \pm 5.6$ \\
\hline & North & $36 \pm 3.9$ & $51 \pm 8.1$ & $39 \pm 8.7$ & \\
\hline & East & $44 \pm 9.5$ & $49 \pm 7.5$ & $39 \pm 8.1$ & \\
\hline & South & $54 \pm 8.0$ & $59 \pm 5.9$ & $48 \pm 4.5$ & \\
\hline & West & $41 \pm 4.7$ & $40 \pm 6.4$ & $38 \pm 10.1$ & \\
\hline \multirow[t]{5}{*}{ DHA } & CEN r & $7.7 \pm 2.1$ & $9.1 \pm 5.1$ & $8.3 \pm 0.8$ & $15.0 \pm 5.3$ \\
\hline & North & $7.0 \pm 1.5$ & $9.6 \pm 1.9$ & $7.9 \pm 1.4$ & \\
\hline & East & $8.6 \pm 3.0$ & $8.5 \pm 2.0$ & $8.9 \pm 1.5$ & \\
\hline & South & $10 \pm 5.3$ & $12 \pm 2.0$ & $11 \pm 3.0$ & \\
\hline & West & $8.0 \pm 2.4$ & $8.8 \pm 3.4$ & $8.4 \pm 3.1$ & \\
\hline \multirow[t]{5}{*}{$\mathrm{C}$} & CENr & $3.6 \pm 1.1$ & $4.1 \pm 1.2$ & $3.7 \pm 0.8$ & $5.2 \pm 1.6$ \\
\hline & North & $3.2 \pm 0.9$ & $4.2 \pm 0.7$ & $3.8 \pm 1.2$ & \\
\hline & East & $3.2 \pm 1.3$ & $4.4 \pm 1.4$ & $3.5 \pm 0.8$ & \\
\hline & South & $3.6 \pm 2.3$ & $4.4 \pm 0.7$ & $3.8 \pm 1.1$ & \\
\hline & West & $3.3 \pm 0.5$ & $4.1 \pm 1.0$ & $3.4 \pm 1.0$ & \\
\hline \multirow[t]{5}{*}{$\mathrm{N}$} & CEN & $1.3 \pm 0.2$ & $1.6 \pm 0.2$ & $2.0 \pm 1.0$ & $2.4 \pm 0.3$ \\
\hline & North & $1.2 \pm 0.2$ & $1.5 \pm 03$ & $2.0 \pm 0.9$ & \\
\hline & East & $1.1 \pm 0.3$ & $1.7 \pm 0.4$ & $1.7 \pm 0.4$ & \\
\hline & South & $1.6 \pm 0.1$ & $1.9 \pm 0.2$ & $2.5 \pm 0.4$ & \\
\hline & West & $1.5 \pm 0.3$ & $1.5 \pm 0.3$ & $1.7 \pm 0.5$ & \\
\hline \multirow[t]{5}{*}{$\mathrm{K}^{+}$} & CEN & $147 \pm 75.5$ & $212 \pm 144.3$ & $192 \pm 103.5$ & $312 \pm 68.3$ \\
\hline & North & $160 \pm 80.1$ & $238 \pm 161.1$ & $187 \pm 99.6$ & \\
\hline & East & $160 \pm 62.3$ & $244 \pm 75.4$ & $177 \pm 74.3$ & \\
\hline & South & $260 \pm 94.7$ & $268 \pm 80.1$ & $190 \pm 100.4$ & \\
\hline & West & $150 \pm 78.3$ & $250 \pm 101.6$ & $167 \pm 92.8$ & \\
\hline \multirow[t]{5}{*}{$\mathrm{MBC}$} & CEN & $3100 \pm 295$ & $3900 \pm 311$ & $2010 \pm 279$ & $3570 \pm 294$ \\
\hline & North & $3370 \pm 175$ & $4400 \pm 293$ & $1700 \pm 313$ & \\
\hline & East & $3500 \pm 221$ & $4770 \pm 315$ & $1990 \pm 274$ & \\
\hline & South & $3990 \pm 337$ & $4660 \pm 339$ & $2400 \pm 364$ & \\
\hline & West & $3010 \pm 365$ & $4220 \pm 359$ & $1900 \pm 240$ & \\
\hline
\end{tabular}

The number of water-soluble phenols was significantly higher in gaps than in the forest site, and WSP did not change significantly with the size of the gaps $(p=0.67)$. No significant differences $(p=0.56)$ were detected among the four different cardinal directions and the center for all gaps.

FDA activity was significantly higher $(p \leq 0.05)$ in the forest site than in the gaps, with significantly higher values in the medium gaps. In the large and small gaps, FDA activity changed significantly between the center and the cardinal directions. In each gap, the highest FDA activity was detected in the south (Table 2). DHA activity was significantly higher $(p \leq 0.05)$ in the forest site than in the gaps, with trend similar to FDA, and significantly higher in the medium gaps, with significantly changes between the center and the cardinal directions. The highest activity was observed in the south of each gap. Potassium was more abundant in forest followed by medium gaps. The lowest amount was found in the small gaps. MBC was greater in medium than the other sites and it was more abundant in south and east cardinal directions inside medium gaps.

\subsection{Natural Regeneration}

For each gap size, the Pearson correlation coefficients $(r$ ) (Figure 3) showed the re- 
lationships between the beech regeneration density (number of seedlings per $\mathrm{m}^{2}$ ) and microclimatic variables. In the medium gaps the regeneration density was significantly correlated with soil moisture (positive correlation) and soil temperature (negative correlation), while the correlation with PAR (negative correlation) was not significant. In the small and large gaps, the regeneration density was never significantly correlated with microclimatic variables. For each size of the gap, no interaction terms between the microclimatic variables had a significant effect on the regeneration density (results non-reported).

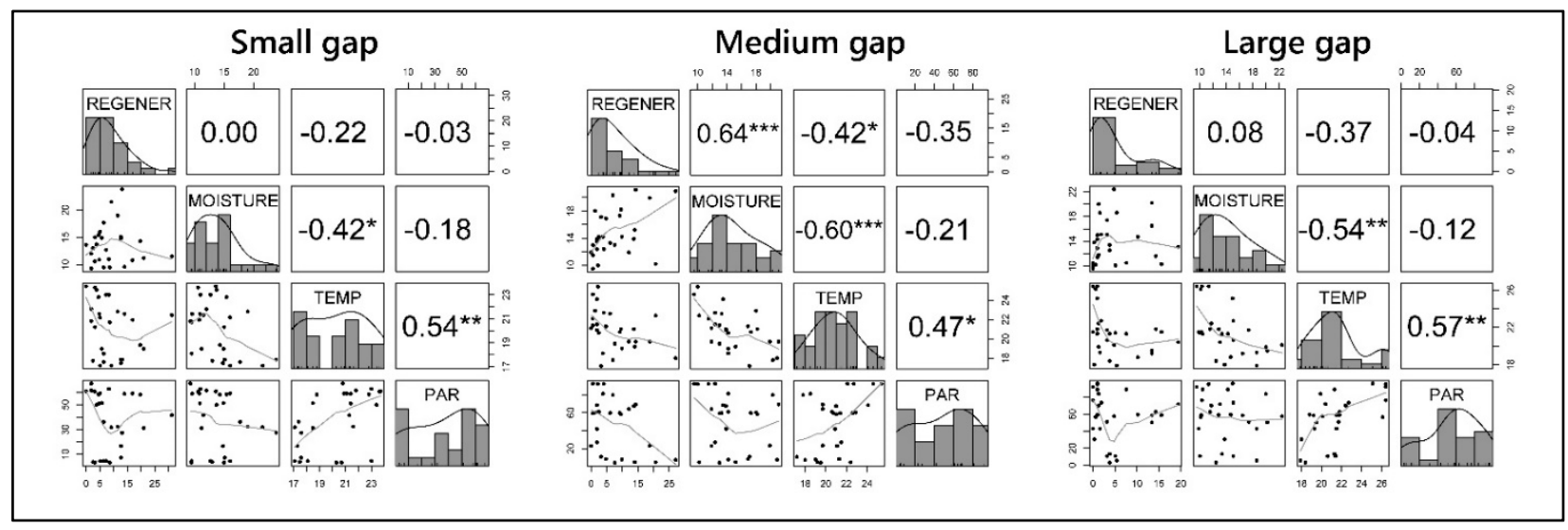

Figure 3. Scatterplot matrix with Pearson correlations. REGENER, natural regeneration; MOISTURE, soil moisture; TEMP, soil temperature; PAR, photosynthetically active radiation. For each gap size, $n=27$. Asterisks stand for $p$-values: ${ }^{* * *}: p<0.001 ; * *: p<0.01 ;{ }^{*} p<0.05$.

Table 3 shows the results obtained with nbGLM, to evaluate the effect of predictor variables on seedling counts. While the gap size, position, and cardinal directions had a significant effect on regeneration density, the interactions between the predictive variables were not significant. Particularly, the beech seedlings number per meter square $\left(\mathrm{m}^{2}\right)$ decreased with increasing gap size (Figure $4 \mathrm{~A}$ ), with a significant difference in regeneration density between small gap ( 8.1 seedlings per $\mathrm{m}^{2}$ ) and large gap ( 5 seedlings per $\mathrm{m}^{2}$ ). The regeneration density in the medium gaps $\left(7.4\right.$ seedlings per $\left.\mathrm{m}^{2}\right)$ did not show significant differences with either the small or large gaps. Also, the position (edge or center) and the cardinal directions had a significant effect on seedlings number (Table 3 and Figure $4 B, C)$. Particularly, the number of seedlings was significantly higher in the central area of the gap (9.1 seedlings per $\left.\mathrm{m}^{2}\right)$ than the edge of the gap (4.6 seedlings per $\left.\mathrm{m}^{2}\right)$. In the medium gaps, the differences were not significant, as a more homogeneous distribution of the natural regeneration occurred here. Referring to cardinal directions (Figure 4C), the number of seedlings was significantly higher in the South $\left(9.5\right.$ seedlings per $\left.\mathrm{m}^{2}\right)$ and east (8.4 seedlings per $\mathrm{m}^{2}$ ) than in the other cardinal directions, among which no significant differences in regeneration density emerged. In the north, the lowest regeneration density was found ( 4.5 seedlings per $\mathrm{m}^{2}$ ) (Figure $4 \mathrm{C}$ ).

Table 3. Estimates of explanatory variables' coefficients for the negative binomial generalized linear model (nbGLM) to evaluate the effect of predictor variables on seedling counts. NS, not significant; ${ }^{*} p<0.05 ;{ }^{* *} p<0.01 ;{ }^{* * *} p<0.001$.

\begin{tabular}{cccccc}
\hline & Estimate & Std. Error & $z$ Value & $\operatorname{Pr}(>|\mathbf{z}|)$ & Sig. \\
\hline Intercept & 1.8973 & 0.1790 & 10.599 & $<2.0 \mathrm{e}-16$ & $* * *$ \\
GAP SIZE & 0.0014 & 0.0003 & 5.407 & $6.4 \mathrm{e}-08$ & $* * *$ \\
Center & 0.7012 & 0.0946 & 7.409 & $1.3 \mathrm{e}-13$ & $* * *$ \\
East & 0.3037 & 0.1487 & 2.043 & $4.1 \mathrm{e}-02$ & $*$ \\
North & -0.2742 & 0.1660 & -1.652 & $9.8 \mathrm{e}-02$ & - \\
South & 0.4828 & 0.1448 & 3.334 & $9.0 \mathrm{e}-04$ & $* *$ \\
West & 0.0264 & 0.1560 & 0.169 & $8.6 \mathrm{e}-01$ & - \\
\hline
\end{tabular}




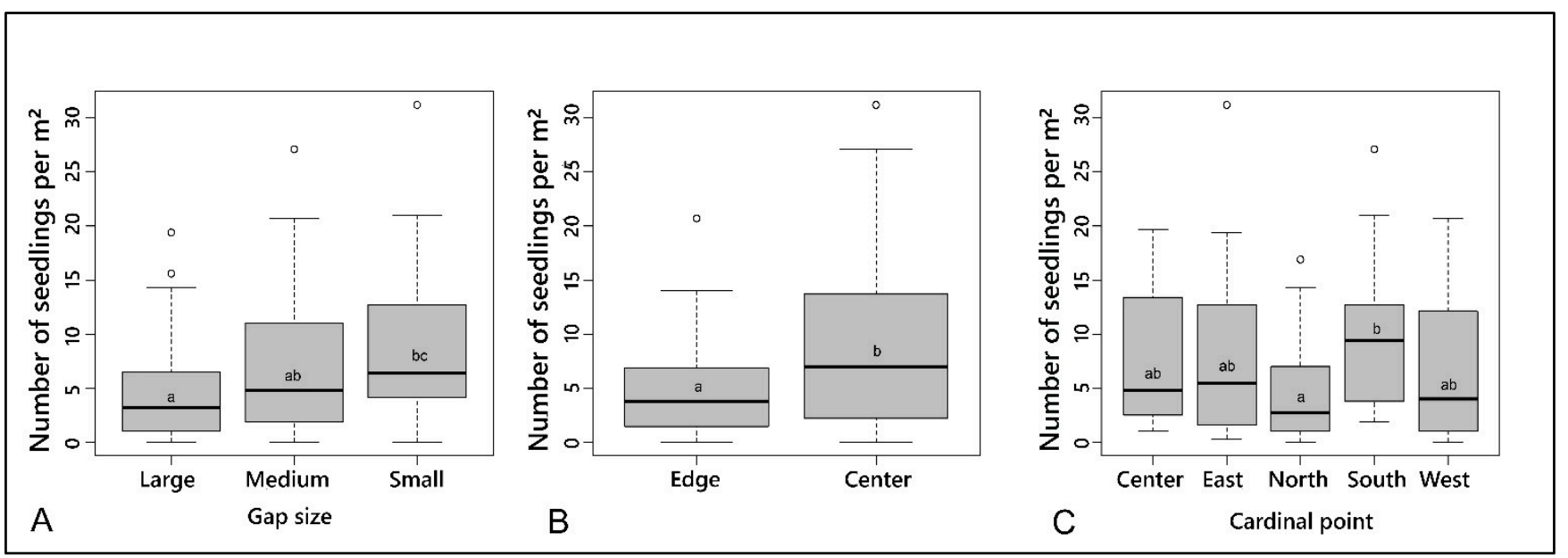

Figure 4. Number of seedlings per $\mathrm{m}^{2}$ per gap-size (A), number of seedlings in the edge and in the center of gaps (B), in cardinal point (C). The box plots explanations are as in Figure 2, with the difference of the median values represented here by the heavy horizontal line. Boxes with different letters indicate significant differences in number of seedlings per $\mathrm{m}^{2}$ $(p<0.05)$.

\subsection{BAI Values and Tree Ring Width}

For each gap size, Figure 5 shows the BAI values obtained for trees sampled in each cardinal point and for trees sampled in forest, outside the gaps. In general, BAI increased over time for all trees. Until 2008-2010, BAI values, although varying from year to year between different conditions, had a similar trend. Later (after the gap's opening), trees had higher BAI in the south in medium and small gaps and in the east and south in large gaps, while had a lower BAI in the north and west in each gap. Finally, for trees sampled in forest, BAI values similar to the trees sampled in the gap were observed until 2009-2010. Later, a consistent decrease BAI values were observed for the period 2010-2019.

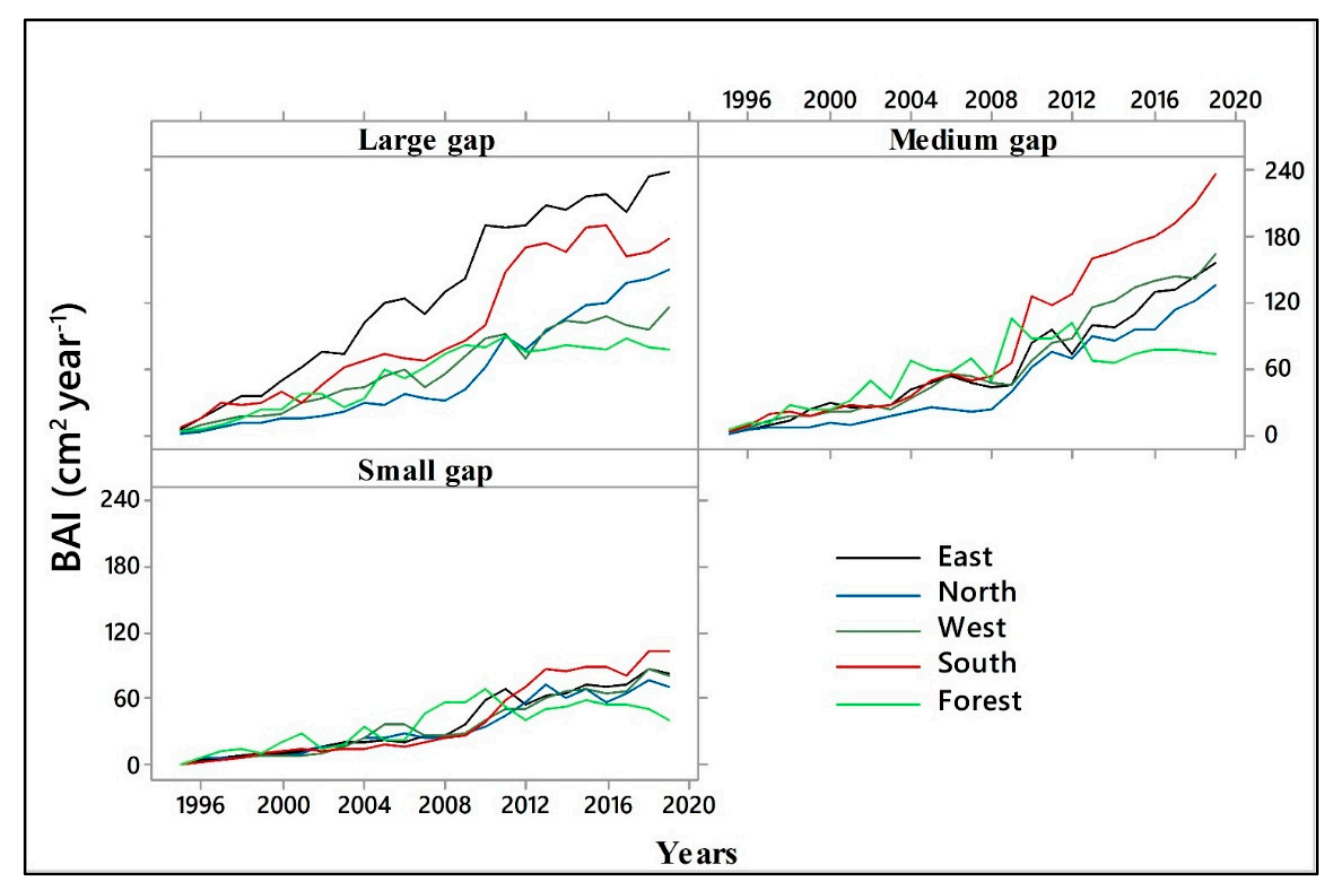

Figure 5. Basal area increment (BAI) values trend for European beech in each size gap and for each cardinal point.

For each gap size and for each year, Figure 6 shows the variability and median values of trees ring width, both for the trees sampled in forest and in the gaps. Overall, the 
observed variability was always very high in each year, especially for trees sampled in the large gaps. Furthermore, for all trees the rings width showed minor changes between different years, at least until 2009 (the year the gaps were opened). Later, the tree ring width tended to increase in the trees sampled in the gaps, regardless of the gap size. However, in the trees sampled in the large gaps, the ring width showed the highest values in the two to three years following the gap formation, and then gradually decreased. On the contrary, in the trees sampled in the medium gaps, and also partly in the small gaps, the ring width increased after gap opening and continued to show the high growth for several years. It decreased solely in the last two years.

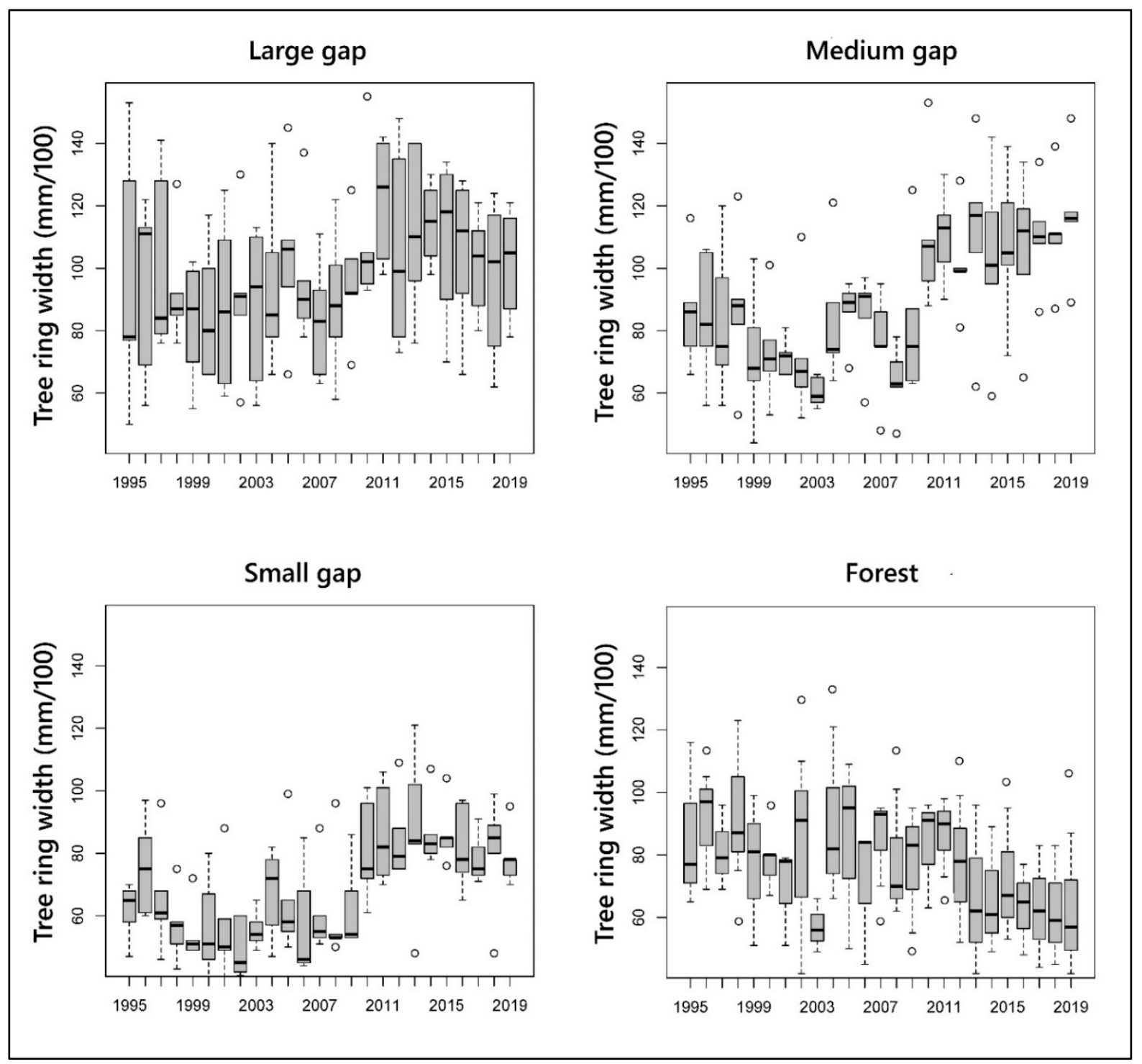

Figure 6. Variability and median values of ring width related to tree sampled in each gap (large medium and small) and in forest. The box plots explanations are as in Figure 2, with the difference of the median values represented here by the heavy horizontal line. The values are expressed in 100th of a millimeter $(\mathrm{mm} / 100)$.

The trend of the tree ring width sampled in forest, not near the gaps, appeared to be different. While in the period from 1995 to 2009 the growth was in line with the growth of the trees sampled in the gaps (on average $0.81 \mathrm{~mm}_{\text {year }}{ }^{-1}$ ), subsequently the rings width gradually decreased (on average $0.72 \mathrm{~mm}_{\text {year }}{ }^{-1}$ ), but without significant differences between the two periods (Table 4). On the contrary, the tree ring width sampled in the gaps 
always showed significant differences between the two periods, with the highest values always recorded after the gaps opening (Table 4).

Table 4. Tree rings widths sampled in gaps and in forest, before and after gap's opening.

\begin{tabular}{ccccc}
\hline & Large Gap & Medium Gap & Small Gap & FOREST \\
\hline Ring Width 1999-2009 $\left(\mathrm{mm} \mathrm{yr}^{-1}\right)$ & $0.94 \pm 0.22$ & $0.74 \pm 0.19$ & $0.58 \pm 0.14$ & $0.81 \pm 0.19$ \\
Ring Width 2010-2019 $\left(\mathrm{mm} \mathrm{yr}^{-1}\right)$ & $1.14 \pm 0.25$ & $1.16 \pm 0.24$ & $0.85 \pm 0.18$ & $0.72 \pm 0.17$ \\
Z-value & 3.853 & 7.863 & 7.542 & 1.899 \\
$p$-value & $<0.0001$ & $<0.0001$ & $<0.0001$ & 0.058 \\
\hline
\end{tabular}

\section{Discussion}

The results provided evidence concerning how the ecological characteristics of gaps were different from the surrounding forest, showing that the gaps were brighter and warmer than the forest due to the increased solar radiation while soils inside the gaps were wetter than the forest. The microclimatic conditions differed significantly on the cardinal directions, independently from the gap size. The highest solar radiation was observed in the north in all gaps, and the lowest in the south evidencing a gradient of increased light from the southern to the northern edge of the gaps as previously reported by many researchers for the northern hemisphere during the growing season [54-58].

Due to the different incidence of PAR, soils into the gaps can have different microclimatic properties [59] which, in turn, differently affected the soil's chemical characteristics. The new created conditions at the soil level can be of crucial importance since they may affect seedling establishment and development and gap floristic composition and structure, as already reported by Zhang et al. [60].

In the gaps, independently from the size, an increase in soil temperature for the direct solar radiation occurred, and the results agree with findings of Malcolm et al. [61]. Soil temperatures did not reach high values for the composition of texture that was prevalently loamy sand. Sariyildiz [62] found in oak, beech, and chestnut stands in the northeast of Turkey $\left(41^{\circ} \mathrm{N}\right)$ an inverse correlation between gap size and temperature increase. In contrast, our results showed that soil temperature increased with increasing gap size, according to results obtained in coniferous stands by other authors [63], in the Pacific Northwest, USA $\left(44-45^{\circ} \mathrm{N}\right)$, and in Southern Apennines, Italy $\left(38^{\circ} \mathrm{N}\right),[52,64]$. These results, even if in some case controversial, showed that a relationship between gap size, air temperature, and soil temperature exists. Our work evidenced that soil temperature was high in the north and in the center of all gaps independently from the size; this agrees with data of Ritter et al. [20]. The rise in temperature in the north side of the gap was also observed by others $[63,65,66]$.

Soil moisture is considered one of the most crucial factors for tree regeneration in Mediterranean forests [67]. The impact of gap opening was particularly significant on soil moisture content, which was higher inside the gaps (14.2\%) than under the surrounding closed canopy $(12 \%)$, for an increase in rainfall and a decrease in transpiration for lacking vegetation $[68,69]$. In our study, a clear correlation between soil moisture and gap sizes was not highlighted, in agreement with Sariyildiz [62] who, in studying temperate hardwoods, did not find differences statistically significant in soil moisture between gaps of different size. Some authors have instead shown that the soil moisture increased with increasing gap size $[52,64,70]$. In our study, the moisture conditions differed significantly on the cardinal directions. The soil moisture was greater in the south of the gaps than the other cardinal directions, according to previous studies [20,57,63,71,72]. Thus, soil moisture varied mostly between the cardinal directions rather than depending on the gap sizes. PAR and soil temperature were responsible for water content and were inversely correlated with soil moisture. PAR and temperature were in fact lower in south direction where moisture was the highest. These results add new insights indicating that the directions influence microenvironmental conditions driving, in turn, soil properties and functioning and is agreement 
with the findings of Ritter et al. [20], Latif and Blackburn, and Kučera et al. [73,74]. Microclimatic conditions play a key role in forest soil processes [75], particularly in organic matter turnover which is intrinsically affected by soil moisture and temperature [76]. In forest gaps, there is a high rate of soil organic matter decomposition and mineralization, leading to increased levels of nutrients [20,77-79]. Increments in ground nitrogen levels were in fact observed in artificially created gaps [80].

Studies of the effects of gap sizes on litter decomposition rates showed conflicting results $[20,62,77,80,81]$. C/N ratio, an index used to monitor the decomposition of litter [82], was the greatest in small gaps (where humification processes prevailed) mostly in north and east part of the gaps and the lowest in large gaps (where mineralization processes prevailed) in the south and west part of the gaps $[52,64,83]$. In medium gaps, the biological activity was well documented by the highest activities of DHA and FDA, parameters associated with the oxidoreductive and hydrolytic activities of soils and a great potassium content resulting from the catabolism of the organic matter. These biological activities were significantly greater in the south of the gaps. This suggested that in the medium gaps there was a better balance between humification and mineralization processes. In the small gaps, the humification of organic matter prevailed due to lower microbial activity. Conversely, in the large gaps a higher mineralization process was demonstrated by a lower $\mathrm{C} / \mathrm{N}$ ratio. The best soil biological conditions occurred in the medium gaps and the south was the better direction for the soil functioning.

These climatic and soil conditions inside the gaps influenced both beech natural regeneration and tree growth at the edges of the gaps. In fact, the European beech regeneration, expressed as the number of seedlings per $\mathrm{m}^{2}$, was significantly influenced by the gap size. On the other hand, recent studies resulted that the gap sizes may have an influence on establishment and growth of different tree species [24,84,85], confirming the strict dependence of natural tree regeneration with light and soil characteristics affected by light changes.

In our study, in the small gaps the beech regeneration density was significantly greater than in the large ones, but with no significant differences with the medium gaps. Mountford et al. [86], in a managed beechwood in southern England, and Gálhidy et al. [87], in a temperate deciduous forest found more prolific beech regeneration in small and medium gaps. Our results are also consistent with previous studies [32,88], reporting that European beech grew optimally in gap openings minor than $500 \mathrm{~m}^{2}$. In short, our result highlighted that in the small and medium gaps, the combination of moderate levels of diffuse light and relatively low levels of direct light created more favorable conditions in soil moisture and nutrients, particularly for nitrogen and potassium whose presence is important for beech natural regeneration (species shade tolerant), confirming previous observations of other authors $[58,89,90]$. As observed by Čater and Diaci and Hammond and Pokorný, [85,91], the small and medium gaps are generally beneficial for the regeneration of shade-tolerant species, whereas large gaps are more adapt for light-adapted ones, suggesting that the natural regeneration of species with different light-feeling can be steered with the size and distribution of gaps.

In this study, it was found that there is a significant relationship between regeneration density and cardinal directions, evidencing that the European beech regeneration and the regeneration of shade-intolerant species may not be ascribed only to the gap size but also to the cardinal directions. According to Hammond and Pokorny [33], we found a greater beech regeneration density in the central area of the gaps compared to the outermost one, with a major density in south and east directions, only in the medium gaps. This result was consistent with the study of Orman et al. [9] carried on in an old growth forest in central Poland, where the highest densities of beech seedlings were observed in plots located in gap center (as in our study). In contrast, the study of Vilhar et al. [92] showed that in a beech forest located in south-eastern Slovenia, the highest regeneration density was found along the edges of the gaps rather than in the center of the gaps. Orman et al. [9] found that beech seedlings were only affected by cardinal direction and not by gap size and that the 
highest densities of beech seedlings were observed along east (as in our study) and west (unlike our study) directions. Nagel et al. (2010) Diaci et al., and Orman et al. [24,30,31], showed that large gaps can be crucial in promoting beech to taller life stages, believing that the gap size may influence the establishment and growth of species in different manner depending on species life stage (seedling, sapling, trees).

In our study, in the Mediterranean environment, in the large gaps the north position received the highest direct light levels ( $\mathrm{PAR}=84.2 \%$ ), while soil moisture values $(12.7 \%)$ were the lowest. It is likely that these ecological factors can be the cause of a lesser beech natural regeneration in the large gaps. In beech forest stands located in Central Bohemia (Czech Republic), Bílek et al. [90] showed that the ecological factors had an important role to explain the scarce regeneration density, as well as the limited cover of ground vegetation in large gap [54]. These findings suggested that the beech regeneration in forest stands was driven by gap openings, but not necessarily by the direct radiation [93], which mainly occurred at the northern edge of large gaps where we found a sparse beech natural regeneration. The results of our study allowed us to state that moisture had a very significant effect on European beech regeneration in medium gaps but not in small and large gaps (Figure 3). On the contrary, the increase in soil temperature had a significant negative effect on beech regeneration in medium gaps and non-significant effects in small and large gaps.

On the other hand, soil moisture is one of the most important parameters for tree regeneration in Mediterranean forests and soil moisture content was particularly significant in the medium gaps (Figure 2). This, together with the low temperature, resulted in a greater natural regeneration. Indeed, the temperature and moisture are negatively correlated with each other (Figure 3), and European beech trees prefer low temperatures. Therefore, the difference among the gaps can be related to a complex cross of data due to moisture and temperature but also undercover vegetation amount, which in turn can affect nutrient cycles in soil.

The PAR increased as the gap size increased, but without a significant effect on beech regeneration in any gap. These results contradicted a remark of Sedmáková et al. [94] that European beech regeneration and growth was temperature-driven but confirmed data of Farahat and Linderholm [95] showing that European beech is less sensitive to temperature than other parameters, as also emerged in our study, where moisture was observed to have influenced beech natural regeneration very significantly in medium gaps $(\mathrm{r}=0.68, p<0.01)$.

The new microclimatic conditions due to the gap opening had effects on the tree growth. Indeed, all of the trees located along the gap edge recorded higher productivity compared to the period prior to the gap opening, as showed by the rapid increase in the BAI values, especially in the trees sampled on the edges of the medium gaps. On the contrary, the trees located in the forest recorded BAI values coherent with the period prior the gap opening. Trees located at the south and east had grater increments than trees located at the north and west, especially in the medium gaps. The lower growth of trees located in the north may depend on the highest direct light levels that generally the northern margin of the gaps received, and the consequent lowest soil moisture values. The latter was probably a result of high temperatures, high evaporation, and root competition from gap edge trees [90].

Our results confirm that medium-sized gaps can create the ideal conditions to favor the beech growth and regeneration. In natural processes of temperate forests, large gaps are rather rare $[28,96]$. In beech-dominated forests, the gaps larger than $400 \mathrm{~m}^{2}$ are considered rare events $[97,98]$.

\section{Conclusions}

Considering that silvicultural operations favor natural regeneration respecting nature, this study confirmed the important effect of the size of the gaps but mostly highlighted the key role of cardinal directions inside the gaps on modulating micro-environmental parameters, soil properties, and biological processes. The cardinal directions affected 
the natural regeneration of beech which regenerated more in the south part of the gaps followed by the center, east, west, and north. Thus, the microclimate was different at the different cardinal directions, creating in each point different conditions for tree natural regeneration. Regarding gap size, in this study, medium gaps appeared to be the most sustainable in terms of soil quality, maintaining the right balance between humification and mineralization process and good microbial activity. In medium gaps, the combination and interaction of microclimatic and soil parameters created the best conditions for the beech natural regeneration and favored an increase in the productivity of the trees at the edge of the gaps.

Author Contributions: A.M.: conceived and designed the experiments, analyzed the data, and wrote the manuscript. P.A.M. and M.S.: analyzed the data, performed statistical analyses, and critically reviewed and edited the manuscript. S.B., C.M. and F.M. performed the laboratory experiments and collected the data in field. All authors have read and agreed to the published version of the manuscript.

Funding: This research did not receive any specific grant from funding agencies in the public.

Data Availability Statement: Data are contained within the article.

Conflicts of Interest: The authors declare no conflict of interest.

\section{References}

1. Puettmann, K.J.; Coates, K.D.; Messier, C. A Critique of Silviculture; Managing for Complexity; Island Press: Washington, DC, USA, 2009.

2. Conti, F.; Abbate, G.; Alessandrini, A.; Blasi, C. An Annotated Checklist of the Italian Vascular Flora; Palombi Editore: Roma, Italy, 2005.

3. Marziliano, P.A.; Antonucci, S.; Tognetti, R.; Chirici, G.; Corona, P.; Lombardi, F. Factors affecting the quantity and type of tree-related microhabitats in Mediterranean mountain forests of high nature value. iForest 2021, 14, 250-259. [CrossRef]

4. Nocentini, S.; Buttoud, G.; Ciancio, O.; Corona, P. Managing forests in a changing world: The need for a systemic approach. A review. For. Syst. 2017, 26, eR01. [CrossRef]

5. Gardiner, B.; Blennow, K.; Carnus, J.M.; Fleischer, P.; Ingemarson, F.; Landmann, G.; Lindner, M.; Marzano, M.; Nicoll, B.; Orazio, C.; et al. Destructive Storms in European Forests: Past and Forthcoming Impacts. European Forest Institute: Atlantic European Regional Office. Final Report to DG Environment (07.0307/2009/SI2.540092/ETU/B.1). 2010, p. 138. Available online: https: / / www.researchgate.net/publication/234080766_Destructive_storms_in_European_forests_past_and_forthcoming_impacts (accessed on 4 November 2021).

6. Thom, D.; Seidl, R.; Steirer, G.; Krehan, H.; Formayer, H. Slow and fast drivers of the natural disturbance regime in Central European forest ecosystems. For. Ecol. Manag. 2013, 307, 293-302. [CrossRef]

7. Thom, D.; Seidl, R. Natural disturbance impacts on ecosystem services and biodiversity in temperate and boreal forests. Biol. Rev. 2016, 91, 760-781. [CrossRef]

8. Kulakowski, D.; Svoboda, M.; Bebi, P. The central role of disturbances in mountain forests of Europe. For. Ecol. Manag. 2017, 388, 1-2. [CrossRef]

9. Orman, O.; Wrzesinski, P.; Dobrowolska, D.; Szewczyk, J. Regeneration growth and crown architecture of European beech and silver fir depend on gap characteristics and light gradient in the mixed montane old-growth stands. For. Ecol. Manag. 2021, 482, 118866. [CrossRef]

10. Bottero, A.; Garbarino, M.; Dukic, V.; Govedar, Z.; Lingua, E.; Nagel, T.A.; Motta, R. Gapphase dynamics in the old-growth forest of Lom, Bosnia and Herzegovina. Silva Fenn. 2011, 45, 875-887. [CrossRef]

11. Nagel, T.A.; Svoboda, M. Gap disturbance regime in an old-growth Fagus-Abies forest in the Dinaric Mountains, BosniaHerzegovina. Can. J. For. Res. 2008, 38, 2728-2737. [CrossRef]

12. Rentch, J.S.; Schuler, T.M.; Nowacki, G.J.; Beane, N.R.; Ford, W.M. Canopy gap dynamics of second-growth red spruce-northern hardwood stands in West Virginia. For. Ecol. Manag. 2010, 260, 1921-1929. [CrossRef]

13. Muscolo, A.; Bagnato, S.; Sidari, M.; Mercurio, R. A review of the roles of forest canopy gaps. J. For. Res. 2014, 25, 725-736. [CrossRef]

14. Jaloviar, P.; Sedmáková, D.; Pittner, J.; Danková, L.J.; Kucbel, S.; Sedmákand, R.; Saniga, M. Gap structure and regeneration in the mixed old-growth forests of National Nature Reserve Sitno, Slovakia. Forests 2020, 11, 81. [CrossRef]

15. Schliemann, S.; Bockheim, J. Methods for studying treefall gaps: A review. For. Ecol. Manag. 2011, 261, 1143-1151. [CrossRef]

16. Marziliano, P.A.; Coletta, V.; Scuderi, A.; Scalise, C.; Menguzzato, G.; Lombardi, F. Forest structure of a maple old-growth stand: A case study on the Apennines mountains (Southern Italy). J. Mt. Sci. 2017, 14, 1329-1340. [CrossRef]

17. Muscolo, A.; Settineri, G.; Bagnato, S.; Mercurio, R.; Sidari, M. Use of canopy gap openings to restore coniferous stands in Mediterranean environment. iForest 2017, 10, 322-327. [CrossRef]

18. Košulič, O.; Michalko, R.; Hula, V.; Heneberg, P. Impact of canopy openness on spider communities: Implications for conservation management of formerly coppiced Oak forests. PLoS ONE 2016, 11, e0148585. [CrossRef] 
19. Wu, C.D.; Cheng, C.C.; Chang, C.C.; Lin, C.; Chang, K.C.; Chuang, Y.C. Gap shape classification using landscape indices and multivariate statistics. Sci. Rep. 2016, 6, 38217. [CrossRef] [PubMed]

20. Ritter, E.; Dalsgaard, L.; Einhorn, K.S. Light, temperature and soil moisture regimes following gap formation in a semi-natural beech-dominated forest in Denmark. For. Ecol. Manag. 2005, 206, 1533. [CrossRef]

21. Rozenbergar, D.; Mikac, S.; Anic, I.; Diaci, J. Gap regeneration patterns in relationship to light heterogeneity in two old-growth beech fir forest reserves in South East Europe. Forestry 2007, 80, 431-443.

22. Gray, A.N.; Spies, T.A.; Pabst, R.J. Canopy gaps affect long-term patterns of tree growth and mortality in mature and old-growth forests in the Pacific Northwest. For. Ecol. Manag. 2012, 281, 111-120. [CrossRef]

23. Stan, A.B.; Daniels, L.D. Growth releases across a natural canopy gap-forest gradient in old-growth forests. For. Ecol. Manag. 2014, 313, 98-103. [CrossRef]

24. Orman, O.; Dobrowolska, D.; Szwagrzyk, J. Gap regeneration patterns in Carpathian old-growth mixed beech forests-Interactive effects of spruce bark beetle canopy disturbance and deer herbivory. For. Ecol. Manag. 2018, 430, 451-459. [CrossRef]

25. Dobrowolska, D.; Boncina, A.; Klumpp, R. Ecology and silviculture of silver fir (Abies alba Mill.): A review. J. For. Res. 2017, 22, 326-335. [CrossRef]

26. Schwarz, J.A.; Bauhus, J. Benefits of mixtures on growth performance of silver fir (Abies alba) and European beech (Fagus sylvatica) increase with tree size without reducing drought tolerance. Front. For. Glob. Chang. 2019, 2, 79. [CrossRef]

27. Zeibig, A.; Diaci, J.; Wagner, S. Gap disturbance patterns of a Fagus sylvatica virgin forest remnant in the mountain vegetation belt of Slovenia. For. Snow Landsc. Res. 2005, 79, 69-80.

28. Drößler, L.; von Lüpke, B. Canopy gaps in two virgin beech forest reserves in Slovakia. J. For. Sci. 2005, 51, 446-457. [CrossRef]

29. Kral, K.; Danek, P.; Janík, D.; Krůcek, M.; Vrska, T. How cyclical and predictable are Central European temperate forest dynamics in terms of development phases? J. Veg. Sci. 2018, 29, 84-97. [CrossRef]

30. Nagel, T.A.; Svoboda, M.; Rugani, T.; Diaci, J. Gap regeneration and replacement patterns in an old-growth Fagus-Abies forest of Bosnia-Herzegovina. Plant Ecol. 2010, 208, 307-318. [CrossRef]

31. Diaci, J.; Adamic, T.; Rozman, A. Gap recruitment and partitioning in an old-growth beech forest of the Dinaric Mountains: Influences of light regime, herb competition and browsing. For. Ecol. Manag. 2012, 285, 20-28. [CrossRef]

32. Čater, M.; Diaci, J.; Roženbergar, D. Gap size and position influence variable response of Fagus sylvatica L. and Abies alba Mill. For. Ecol. Manag. 2014, 325, 128-135. [CrossRef]

33. Hammond, M.E.; Pokorný, R. Effects of gap size on natural regeneration and microenvironmental soil conditions in European beech (Fagus sylvatica L.) and Norway spruce (Picea abies (L.) Karst) dominated mixed forest. Plant Soil Environ. 2020, 66, 607-615. [CrossRef]

34. FAO World Reference Base for Soil Resources. International Soil Classification System for Naming Soils and Creating Legends for Soil Maps. In World Soil Resources Reports; No. 106; FAO: Roma, Italy, 2014.

35. Rivas-Martinez, S. Clasificacion Bioclimàtica de la tierra. Folia Bot. Madritensis 1996, 16, 1-32.

36. Ciancio, O.; Iovino, F.; Mendicino, V.; Menguzzato, G.; Nicolaci, A.; Nocentini, S. Structure and management of Aleppo pine forests. Options Méditerranéennes Ser. A 2008, 75, 61-72.

37. Nocentini, S. Structure and management of beech (Fagus sylvatica L.) forests in Italy. iForest 2009, 2, 105-113. [CrossRef]

38. Russo, D.; Marziliano, P.A.; Macrì, G.; Proto, A.R.; Zimbalatti, G.; Lombardi, F. Does thinning intensity affect wood quality? An analysis of Calabrian pine in Southern Italy using a non-destructive acoustic method. Forests 2019, 10, 303. [CrossRef]

39. Marziliano, P.A.; Tognetti, R.; Lombardi, F. Is tree age or tree size reducing height increment in Abies alba Mill. at its southernmost distribution limit? Ann. For. Sci. 2019, 76, 17. [CrossRef]

40. Russo, D.; Marziliano, P.A.; Macrì, G.; Zimbalatti, G.; Tognetti, R.; Lombardi, F. Tree growth and wood quality in pure vs. mixed-species stands of European beech and Calabrian pine in Mediterranean mountain forests. Forests 2020, 11, 6. [CrossRef]

41. Ciancio, O.; Iovino, F.; Menguzzato, G.; Nicolaci, A.; Nocentini, S. Structure and growth of a small group selection forest of Calabrian pine in Southern Italy: A hypothesis for continuous cover forestry based on traditional silviculture. For. Ecol. Manag. 2006, 224, 229-234. [CrossRef]

42. Arseneault, J.E.; Saunders, M.R.; Seymour, R.S.; Wagner, R.G. First decadal response to treatment in a disturbance-based silviculture experiment in Maine. For. Ecol. Manag. 2011, 262, 404-412. [CrossRef]

43. Comeau, P.G.; Gendron, F.; Letchford, T. A comparison of several methods for estimating light under a paper birch mixed wood stand. Can. J. For. Res. 1998, 28, 1843-1850. [CrossRef]

44. Bouyoucos, G.J. Hydrometer method improved for making particle size analysis of soils. Agron. J. 1962, 54, 464-465. [CrossRef]

45. Walkley, A.; Black, I.A. An examination of the Degtjareff method for determining soil organic matter and a proposed modification of the chromic acid titration method. Soil Sci. 1934, 37, 29-38. [CrossRef]

46. Kjeldahl, J. Methode zur bestimmung des stickstoffs in organischen Körpern. Z Anal. Chem. 1883, 22, 366-382. [CrossRef]

47. Kaminsky, R.; Muller, W.H. The extraction of soil phytotoxin using a neutral EDTA solution. Soil Sci. 1977, 124, 205-210. [CrossRef]

48. Kaminsky, R.; Muller, W.H. A recommendation against the use of alkaline soil extraction in the study of allelopathy. Plant Soil 1978, 49, 641-645. [CrossRef]

49. Box, J.D. Investigation of the Folin-Ciocalteau reagent for the determination of polyphenolic substances in natural waters. Water Res. 1983, 17, 511-525. [CrossRef] 
50. Vance, E.D.; Brookes, P.C.; Jenkinson, D.S. An extraction method for measuring soil microbial biomass C. Soil Biol. Biochem. 1987, 19, 703-707. [CrossRef]

51. Adam, G.; Duncan, H. Development of a sensitive and rapid method for the measurement of total microbial activity using fluorescein diacetate (FDA) in a range of soils. Soil Biol. Biochem. 2001, 33, 943-951. [CrossRef]

52. Muscolo, A.; Sidari, M.; Mercurio, R. Variations in soil chemical properties and microbial biomass in artificial gaps in Silver fir stands. Eur. J. For. Res. 2007, 126, 59-65. [CrossRef]

53. Marziliano, P.A.; Menguzzato, G.; Scuderi, A.; Corona, P. Simplified methods to inventory the current annual increment of forest standing volume. iForest 2012, 5, 276-282. [CrossRef]

54. Diaci, J. Regeneration dynamics in a Norway spruce plantation on a silver fir-beech forest site in the Slovenian Alps. For. Ecol. Manag. 2002, 161, 27-38. [CrossRef]

55. Gagnon, J.L.; Jokela, E.J.; Moser, W.K.; Huber, D.A. Dynamics of artificial regeneration in gaps within a longleaf pine flatwoods ecosystem. For. Ecol. Manag. 2003, 172, 133-144. [CrossRef]

56. Mihók, B.; Gálhidy, L.; Kelemen, K.; Standovár, T. Study of gap-phase regeneration in a managed beech forest: Relations between tree regeneration and light, substrate features and cover of ground vegetation. Acta Silv. Lign. Hung. 2005, 1, 25-38.

57. Raymond, P.; Munson, A.D.; Ruel, J.C.; Coates, K.D. Spatial patterns of soil, microclimate, light, regeneration, and growth within silvicultural gaps of mixed tolerant hardwood-white pine stands. Can. J. For. Res. 2006, 36, 639-651. [CrossRef]

58. Diaci, J.; Gyoerek, N.; Gliha, J.; Nagel, T.A. Response of Quercus robur L. seedlings to north-south asymmetry of light within gaps in floodplain forests of Slovenia. Ann. For. Sci. 2008, 65, 105. [CrossRef]

59. Denslow, J.S. Tropical rainforest gaps and tree species diversity. Annu. Rev. Ecol. Syst. 1987, 18, 431-451. [CrossRef]

60. Zhang, X.R.; Tan, X.F.; Wang, R.Q.; Xu, N.N.; Guo, W.H. Effects of soil moisture and light intensity on ecophysiological characteristics of Amorpha fruticosa seedlings. J. For. Res. 2013, 24, 293-300. [CrossRef]

61. Malcom, D.C.; Mason, W.; Clarke, G.C. The transformation of conifer forests in Britain regeneration, gap size and silvicultural systems. For. Ecol. Manag. 2001, 151, 7-23. [CrossRef]

62. Sariyildiz, T. Effects of gap-size classes on long-term litter decomposition rates of beech, oak and chestnut species at high elevations in Northeast Turkey. Ecosystems 2008, 11, 841-853. [CrossRef]

63. Gray, A.N.; Spies, T.A.; Easter, M.J. Microclimate and soil moisture responses to gap formation in coastal Douglas-fir forests. Can. J. For. Res. 2002, 32, 332-343. [CrossRef]

64. Muscolo, A.; Sidari, M.; Mercurio, R. Influence of gap size on organic matter decomposition, microbial biomass and nutrient cycle in Calabrian pine (Pinus laricio Poiret) stands. For. Ecol. Manag. 2007, 242, 412-418. [CrossRef]

65. Bauhus, J. C and N mineralization in an acid forest soil along a gap-stand gradient. Soil Biol. Biochem. 1996, 28, 923-932. [CrossRef]

66. Wright, E.F.; Coates, K.D.; Bartemucci, P. Regeneration from seed of six tree species in the interior cedar-hemlock forests of British Columbia as affected by substrate and canopy gap position. Can. J. For. Res. 1998, 28, 1352-1364. [CrossRef]

67. Sardans, J.; Peñuelas, J. Plant-soil interactions in Mediterranean forest and shrublands: Impacts of climatic change. Plant Soil 2013, 365, 1-33. [CrossRef] [PubMed]

68. Zirlewangen, D.; von Wilpert, K. Modelling water and ion fluxes in a highly structured, mixed species stand. For Ecol. Manag. 2001, 143, 27-37. [CrossRef]

69. Zhu, J.; Matsuzaki, T.; Lee, F.; Gonda, Y. Effect of gap size created by thinning on seedling emergency, survival and establishment in a coastal pine forest. For. Ecol. Manag. 2003, 182, 339-354. [CrossRef]

70. Ochiai, Y.; Okuda, S.; Sato, A. The influence of canopy gap size on soil water condition in a deciduous broad-leaved secondary forest in Japan. J. Jpn For. Soc. 1994, 76, 308-314.

71. Mihók, B.; Gálhidy, L.; Kenderes, K.; Standovár, T. Gap Regeneration Patterns in a Semi-natural Beech Forest Stand in Hungary. Acta Silv. Lign. Hung. 2007, 3, 31-45.

72. Albanesi, E.; Gugliotta, O.I.; Mercurio, I.; Mercurio, R. Effects of gap size and within-gap position on seedlings establishment in silver fir stands. iForest 2008, 1, 55-59. [CrossRef]

73. Latif, Z.A.; Blackburn, G.A. The effects of gap size on some microclimate variables during late summer and autumn in a temperate broadleaved deciduous forest. Int. J. Biometeorol. 2010, 54, 119-129. [CrossRef]

74. Kučera, A.; Holik, L.; Cerro, E.M.; Petříček, J. Effect of gap size and forest type on mineral nitrogen forms under different soil properties. J. For. Res. 2020, 31, 375-386. [CrossRef]

75. Dai, X. Influence of light conditions in canopy gaps on forest regeneration: A new gap light index and its application in a boreal forest in east central Sweden. For. Ecol. Manag. 1996, 84, 187-197. [CrossRef]

76. Buckman, H.O.; Brady, N.C. The Nature and Properties of Soils; The Macmillian Co.: London, UK, 1969.

77. Prescott, C.E.; Hope, G.D.; Blevins, L.L. Effect of gap size on litter decomposition and soil nitrate concentrations in a high elevation spruce-fir forest. Can. J. For. Res. 2003, 33, 2210-2220. [CrossRef]

78. Ritter, E.; Vesterdal, L. Gap formation in Danish beech (Fagus sylvatica) forests of low management intensity: Soil moisture and nitrate in soil solution. Eur. J. For. Res. 2006, 125, 139-150. [CrossRef]

79. Scharenbroch, B.C.; Bockheim, J.G. Gaps and soil C dynamics in old growth northern hardwoodhemlock forests. Ecosystems 2008, 11, 426-441. [CrossRef]

80. Denslow, J.S.; Ellison, A.M.; Sanford, R.E. Treefall gap size effects on above-and below-ground processes in a tropical wet forest. J. Ecol. 1998, 86, 597-609. [CrossRef] 
81. Zhang, Q.; Zak, J.C. Effects of gap size on litter decomposition and microbial activity in a subtropical forest. Ecology 1995, 76, 2196-2204. [CrossRef]

82. Taylor, B.R.; Parsons, W.J.F.; Parkinson, D. Decomposition of Populus tremuloides leaf litter accelerated by addition of Alnus crispa litter. Can. J. For. Res. 1989, 19, 674-679. [CrossRef]

83. Muscolo, A.; Mallamaci, C.; Sidari, M.; Mercurio, R. Effects of gap size and soil chemical properties on the natural regeneration in black pine (Pinus nigra Arn.) stands. Tree For. Sci. Biotechnol. 2011, 5, 65-71.

84. Nagel, T.A.; Mikac, S.; Dolinar, M.; Klopcic, M.; Keren, S.; Svoboda, M.; Diac, J.; Boncina, A.; Paulic, V. The natural disturbance regime in forests of the Dinaric Mountains: A synthesis of evidence. For. Ecol. Manag. 2017, 388, 29-42. [CrossRef]

85. Hammond, M.E.; Pokorný, R. Preliminary assessment of effect of disturbance on natural regeneration in gaps of different sizes. J. For. Sci. 2020, 66, 185-196. [CrossRef]

86. Mountford, E.P.; Savill, P.S.; Bebber, D.P. Patterns of regeneration and ground vegetation associated with canopy gaps in a managed beechwood in southern England. Forestry 2006, 79, 389-408. [CrossRef]

87. Gálhidy, L.; Mihók, B.; Hagyó, A.; Rajkai, K.; Standovár, T. Effects of gap size and associated changes in light and soil moisture on the understorey vegetation of a Hungarian beech forest. Plant Ecol. 2018, 183, 133-145. [CrossRef]

88. Feldmann, E.; Glatthorn, J.; Ammer, C.; Leuschner, C. Regeneration dynamics following the formation of understory gaps in a Slovakian beech virgin forest. Forests 2018, 11, 585. [CrossRef]

89. Wagner, S.; Fischer, H.; Huth, F. Canopy effects on vegetation caused by harvesting and regeneration treatments. Eur. J. For. Res. 2011, 130, 17-40. [CrossRef]

90. Bílek, L.; Remeš, J.; Podrázský, V.; Rozenbergar, D.; Diaci, J.; Zahradník, D. Gap regeneration in near-natural European beech forest stands in Central Bohemia-The role of heterogeneity and micro-habitat factors. Dendrobiology 2014, 71, 59-71. [CrossRef]

91. Čater, M.; Diaci, J. Divergent response of European beech, silver fir and Norway spruce advance regeneration to increased light levels following natural disturbance. For. Ecol. Manag. 2017, 399, 206-212. [CrossRef]

92. Vilhar, U.; Roženbergar, D.; Simončič, P.; Diaci, J. Variation in irradiance, soil features and regeneration patterns in experimental forest canopy gaps. Ann. For. Sci. 2015, 72, 253-266. [CrossRef]

93. Stiers, M.; Willim, K.; Seidel, D.; Ammer, C.; Kabal, M.; Stillhard, J.; Annighöfer, P. Analyzing spatial distribution patterns of European beech (Fagus sylvatica L.) regeneration in dependence of canopy openings. Forests 2019, 10, 637. [CrossRef]

94. Sedmáková, D.; Sedmák, R.; Bosela, M.; Ježík, M.; Blaženec, M.; Hlásny, T.; Marušák, R. Growth climate responses indicate shifts in the competitive ability of European beech and Norway spruce under recent climate warming in East-Central Europe. Dendrochronologia 2019, 54, 37-48. [CrossRef]

95. Farahat, E.; Linderholm, H.W. Growth-climate relationship of European beech at its northern distribution limit. Eur. J. For. Res. 2018, 137, 619-629. [CrossRef]

96. Hobi, M.L.; Commarmot, B.; Bugmann, H. Pattern and process in the largest primeval beech forest of Europe (Ukrainian Carpathians). J. Veg. Sci. 2015, 26, 323-336. [CrossRef]

97. Feldmann, E.; Drößler, L.; Hauck, M.; Kucbel, S.; Pichler, V.; Leuschner, C. Canopy gap dynamics and tree understory release in a virgin beech forest, Slovakian Carpathians. For. Ecol. Manag. 2018, 415, 38-46. [CrossRef]

98. Yamamoto, S.I. Forest gap dynamics and tree regeneration. J. For. Res. 2000, 5, 223-229. [CrossRef] 